\title{
Prevalence and sociodemographic correlates of medication intake adherence among primary health-care users in Albania
}

\author{
Dajana Roshi, ${ }^{1,2}$ Genc Burazeri, ${ }^{1,3}$ Salvatore Italia, ${ }^{1}$ Peter Schröder-Bäck, ${ }^{1}$ Alban Ylli $^{3}$ and Helmut Brand ${ }^{1}$
}

${ }^{1}$ Department of International Health, Care and Public Health Research Institute, Maastricht University, Maastricht, The Netherlands (Correspondence to: D. Roshi: dajana.roshi@maastrichtuniversity.nl). ${ }^{2}$ National Agency for Drugs and Medical Devices, Tirana, Albania and National Agency for Drugs and Medical Devices, Tirana, Albania. ${ }^{3}$ Department of Public Health, Faculty of Medicine, University of Medicine, Tirana, Albania.

\begin{abstract}
Background: Evidence about the magnitude and determinants of medication intake adherence among patients and the general population in Southeastern Europe is scant.

Aims: To assess the prevalence and sociodemographic correlates of medication intake adherence among adult primary health-care (PHC) users in Albania.

Methods: A cross-sectional study was conducted in 2018-2019 in a representative sample of 1553 adult PHC users (response: 94\%) selected probabilistically from 5 major regions of Albania. There were 849 (55\%) women and 704 (45\%) men, with a mean age 54.6 (16.4) years. A structured interviewer-administered questionnaire inquired about medication intake adherence prescribed by family physicians, and sociodemographic characteristics. Binary logistic regression was used to assess the sociodemographic correlates of medication intake adherence.

Results: Three hundred (19.8\%) participants did not take the prescribed medication. In multivariable-adjusted logistic model, significant correlates of nonintake of medication included rural residence, low educational level, unemployment and low economic level. Among these 300 participants, 273 (91\%) considered the high cost of the drugs as a reason for not taking the medication.

Conclusion: We found a high prevalence of nonintake of medication prescribed by family physicians. Decision-makers and policy-makers in Albania and elsewhere should consider the provision of essential drugs free of charge or at low cost to low socioeconomic groups and other vulnerable and marginalized population categories, because the costs of noncompliance will eventually be higher.

Keywords: Albania, cost-related nonadherence, medication adherence, primary health care, sociodemographic factors.

Citation: Roshi D; Burazeri G; Italia S; Schröder-Bäck P; Ylli A; Brand H. Prevalence and sociodemographic correlates of medication intake adherence among primary health-care users in Albania. East Mediterr Health J. 2021;27(5):516-523. https://doi.org/10.26719/emhj.21.008

Received: 29/04/20; accepted: 08/12/20

Copyright (C) World Health Organization (WHO) 2021. Open Access. Some rights reserved. This work is available under the CC BY-NC-SA 3.0 IGO license (https://creativecommons.org/licenses/by-nc-sa/3.o/igo)
\end{abstract}

\section{Introduction}

Health and pharmaceutical policies aim to achieve full coverage of all expenditure, including services and medications $(1,2)$. Hence, effective reimbursement schemes are established globally to minimize out-of-pocket (OOP) expenditure, mainly for prescription-only drugs $(3,4)$. Inability to achieve full coverage of expenses leads to copayments $(5,6)$. Copayments for pharmaceuticals and other healthcare services, which are usually used by health insurers to reduce costs $(4,7)$, may nevertheless incur a heavy financial burden on the population $(4,8)$. This may be especially true in low socioeconomic groups and vulnerable populations that usually suffer the most $(8,9)$.

Medication intake adherence is similar to adherence to medication, but different from compliance, and is the ability of patients to follow healthcare professionals' advice concerning dose regimen, route of administration, and interactions $(10,11)$. There are many reasons for medication nonadherence. Older adults may forgo medication because of cost-related concerns, including lack of adequate prescription coverage by insurance programmes and OOP costs $(12,13)$. Older age, female sex and unemployment may increase nonadherence, even after adjusting for possible confounding variables (14). Healthcare providers consider that educated patients are more likely to be adherent than their less-educated counterparts (14). Arguably, if a patient is highly educated, they should be able to receive the information and stick to it (15). Cost-related nonadherence (CRNA) may be defined as having no access to necessary medication because of limited personal financial resources $(16,17)$.

Albania is a transitional country in the Western Balkans, characterized in the past few decades by rapid political and socioeconomic changes that have been associated with deleterious health effects $(18,19)$. There has been a considerable change in the epidemiological profile of Albania, with a marked increase in noncommunicable diseases $(20,21)$. The main risk factors responsible for the overall burden of disease include arterial hypertension, dietary factors and smoking $(20,21)$. In Albania, medical reimbursement is based on the type of patients and 
medication prescribed $(22,23)$. Not all patients are entitled to full reimbursement for medication because of their category, or because some specific drugs may not be part of the government-approved reimbursement list (24). Regardless of the situation involving medication intake (prescribed vs over the counter), there are many cases where Albanian patients must make copayments $(8,25)$. Many patients are sensitive to even modest increases in OOP expenses (2), whereas others do not reduce their medication because of cost concerns, even when they have a limited ability to pay (17). This situation often raises the question of whether to take the medication prescribed, mainly because of financial reasons $(9,26,27)$.

There is scant evidence about the scale and determinants of medication adherence among Albanian patients at different levels of care, as well as in the general population. The issue of nonadherence to prescribed medication may be of particular concern to several vulnerable and marginalized population subgroups, especially those of low socioeconomic status (21). Such information is necessary to evaluate the implementation of ongoing reforms aimed at ensuring universal health coverage of the Albanian population (21).

The aim of our study was to assess the prevalence and sociodemographic correlates of medication intake adherence among adult primary healthcare (PHC) users in postcommunist Albania. We hypothesized a significantly higher prevalence of medication intake adherence among PHC users with higher socioeconomic status (employed, highly educated and wealthier individuals), and lower adherence among older patients and those with lower socioeconomic status.

\section{Methods}

\section{Study design}

A cross-sectional study was conducted of PHC users in 5 major regions of Albania (Tirana, Shkoder, Vlore, Fier and Diber) during December 2018-January 2019.

\section{Study population and sampling}

We recruited a representative sample of male and female PHC users aged $\geq 18$ years in urban and rural areas of Albania, using a stratified, 2-stage cluster sampling technique in which a region was a stratum and a PHC centre was a cluster.

Based on different conservative assumptions about the prevalence and several sociodemographic correlates of medication adherence among PHC users in Albania, the anticipated minimal sample size was $\sim 870$ participants [the significance level (2-tailed) was set at $5 \%$, and the power of the study at $80 \%$. Sample size was calculated using WINPEPI (28). To account for nonresponse and to increase the study power, allowing for additional and more refined hypothesis testing, we targeted recruitment of 1500 individuals aged $\geq 18$ years (500 in Tirana and 250 in each of the other 4 regions).
In Tirana, 2 PHC centres (with probability proportional to size; PPS) were selected in urban areas and 2 in rural areas (also, with PPS). Conversely, in each of the other 4 regions, 1 PHC centre (with PPS) was selected in urban areas and another (with PPS) in rural areas. In each of the 12 selected PHC centres, consecutive samples of PHC users of both sexes aged $\geq 18$ years were recruited until the anticipated quota was (at least) reached: 500 individuals in Tirana region (250 each in urban and rural areas) and 250 individuals in each of the other 4 regions (125 each in urban and rural areas). During data collection between December 2018 and January 2019, there were 1649 eligible individuals, and 96 were not included in the study: 39 were too sick to be interviewed, and 57 refused to participate. Hence, the study included 1553 individuals: 704 men and 849 women; overall mean age: 54.6 (16.4) years. The overall response rate was $94.2 \%$.

\section{Data collection}

A structured interviewer-administered questionnaire was given to all individuals who agreed to participate. There were 15 interviewers involved in the field work in the 5 regions. All study participants were asked about adherence to medication prescribed by their family physicians. A total of 1516 individuals (98\%) provided information about adherence to prescribed medication, whereas the remaining 37 were not prescribed medication. Three hundred participants who reported nonintake of medication prescribed by their family physicians were additionally asked to indicate which of the following 3 reasons were responsible for not taking the prescribed medication: high cost of the medication; treatment negligence (forgetting and/or skipping intake); and mistrust in the effectiveness/quality of the medication prescribed.

Demographic data included age (trichotomized into: $<40,40-64.9$ and $\geq 65$ years) and sex, marital status (dichotomized into: married vs other categories - which included single, cohabiting, divorced or widowed), and place of residence (urban vs rural). Socioeconomic factors included educational attainment [low ( $0-8$ years of formal schooling), middle (9-12 years), and high ( $\geq 13$ years)], employment status (employed, unemployed or retired), and self-perceived economic level (dichotomized into: low vs not low).

Before conducting the survey, the whole questionnaire was initially pretested in November 2018 in 2 PHC centres in urban and rural areas of Tirana region. All survey questions were clearly understood by participants in different sociodemographic categories. The pretesting revealed comparable participation rates (95-97\%) among different demographic and socioeconomic groups.

\section{Ethics}

The study was approved by the Albanian Committee of Bio-Medical Ethics in November 2018. All participants included in this analysis gave their consent after being informed about the aims and procedures of the study. 


\section{Data analysis}

Fisher's exact test was used to compare the distribution of sociodemographic characteristics of PHC users by medication adherence based on the prescriptions provided by their respective family physicians. Binary logistic regression was used to assess the demographic and socioeconomic correlates (predictor variables) of medication adherence (outcome variable) among survey participants. Initially, crude (unadjusted) odds ratios (ORs: nonintake vs intake of medication prescribed by family physicians), their respective 95\% confidence intervals (95\% CIs) and P values were calculated. Subsequently, multivariable-adjusted logistic regression models were constructed, controlling simultaneously for all the sociodemographic factors (age, sex, marital status, residence, education, employment and economic status). Multivariable-adjusted ORs, their respective 95\% CIs and $P$ values were calculated. The multivariable logistic regression model met the goodness-of-fit criterion as appraised by the Hosmer-Lemeshow test (29). For all statistical tests, $P \leq 0.05$ was considered statistically significant. All statistical analyses were performed using SPSS version 19.0.

\section{Results}

The overall response rate was $94.2 \%$. About $23 \%$ of study participants were aged $18-40$ years, whereas $33 \%$ were $\geq$ 65 years. About $82 \%$ of individuals were married; $~ 58 \%$ were urban residents; $\sim 43 \%$ had a low educational attainment ( $\leq 8$ years of formal schooling); whereas $\sim 23 \%$ had a higher educational level ( $\geq 13$ years of formal schooling); $\sim 29 \%$ were unemployed. The prevalence of self-perceived low economic status was 30\% (data not shown).

Overall, 1516 individuals ( $98 \%$ of participants) provided information on adherence to medication prescribed by their respective family physicians (37 individuals were not prescribed medication). Of these, 1216 (80.2\%) reported intake of the medication prescribed by their family physicians, whereas the remaining 300 (19.8\%) did not take the prescribed medication. An analysis restricted to participants aged $\geq 55$ years revealed a prevalence of nonintake of $18 \%$.

Table 1 presents the sociodemographic characteristics of 1516 PHC according to medication adherence. There was no significant difference in prevalence of medication adherence between men and women, or married versus unmarried individuals. Conversely, the prevalence of medication adherence was significantly higher among older participants ( $\geq 65$ years) than their middle-age (40-64.9 years) counterparts. The prevalence of medication adherence was significantly higher among urban than rural residents; among participants with higher educational attainment than in those with a low educational level; among employed compared to unemployed individuals; and among individuals with a middle and/or high economic status compared with low economic status.

In crude (unadjusted) logistic regression models (Table 2), there was evidence of a positive and significant association of medication nonadherence with middle age (40-64.9 years), rural residence, low education level, unemployment and, in particular, economic level. In multivariable-adjusted logistic regression models, significant correlates of medication nonadherence were: nonmarried status, rural residence, low education level, unemployment, and especially, low economic status. About $22 \%$ of medication nonadherence was explained by the sociodemographic factors introduced into the multivariable-adjusted logistic regression models.

Among 300 participants who reported nonintake of medication prescribed by their respective family physicians (19.8\% of the overall sample of 1516 individuals with valid data on medication adherence), 91\% considered the high cost of the drugs as the main reason for not taking the medication (Table 3 ). Additionally, $48 \%$ of participants reported negligence (forgetting and/or skipping intake of medications) as the second major reason for not taking the prescribed medication. Furthermore, $46 \%$ of these participants stated that mistrust in the effectiveness (quality) of the drugs prescribed was the third major reason for not taking the medication. Interestingly, 45\% of participants in this subsample reported all 3 reasons for nonintake of medication prescribed by their family physicians. Conversely, there were 7 (2.3\%) participants who did not report any reasons for not taking the medication.

\begin{tabular}{|c|c|c|c|}
\hline \multicolumn{4}{|c|}{$\begin{array}{l}\text { Table } 1 \text { Sociodemographic characteristics and adherence } \\
\text { to medication prescribed by family physicians of primary } \\
\text { health care users in Albania }\end{array}$} \\
\hline Variable & $\begin{array}{l}\text { Drug } \\
\text { intake } \\
(n=1216)\end{array}$ & $\begin{array}{c}\text { Nonintake } \\
(n=300)\end{array}$ & $\mathbf{P}^{\mathrm{a}}$ \\
\hline $\begin{array}{l}\text { Sex } \\
\quad \text { Male } \\
\text { Female }\end{array}$ & $\begin{array}{l}561(81.9)^{b} \\
655(78.8)\end{array}$ & $\begin{array}{l}124(18.1) \\
176(21.2)\end{array}$ & 0.137 \\
\hline $\begin{array}{l}\text { Age group } \\
\quad<40 \text { years } \\
\quad 40-64.9 \text { years } \\
\geq 65 \text { years }\end{array}$ & $\begin{array}{l}285(81.4) \\
510(77.4) \\
421(83.0)\end{array}$ & $\begin{array}{c}65(18.6) \\
149(22.6) \\
86(17.0)\end{array}$ & 0.045 \\
\hline $\begin{array}{l}\text { Marital status } \\
\text { Married } \\
\text { Other }\end{array}$ & $\begin{array}{l}998(80.9) \\
218(77.3)\end{array}$ & $\begin{array}{l}236(19.1) \\
64(22.7)\end{array}$ & 0.185 \\
\hline $\begin{array}{l}\text { Place of residence } \\
\text { Rural } \\
\text { Urban }\end{array}$ & $\begin{array}{l}460(73.4) \\
756(85.0)\end{array}$ & $\begin{array}{l}167(26.6) \\
133(15.0)\end{array}$ & $<0.001$ \\
\hline $\begin{array}{l}\text { Educational level } \\
\quad \text { Low (0-8 years) } \\
\text { Middle ( } 9 \text {-12 years) } \\
\text { High ( } \geq 13 \text { years) }\end{array}$ & $\begin{array}{l}460(72.0) \\
434(82.7) \\
320(91.7)\end{array}$ & $\begin{array}{l}179(28.0) \\
91(17.3) \\
29(8.3)\end{array}$ & $<0.001$ \\
\hline $\begin{array}{l}\text { Employment status } \\
\text { Employed } \\
\text { Unemployed } \\
\text { Retired }\end{array}$ & $\begin{array}{l}428(88.1) \\
287(66.4) \\
489(83.7)\end{array}$ & $\begin{array}{c}58(11.9) \\
145(33.6) \\
95(16.3)\end{array}$ & $<0.001$ \\
\hline $\begin{array}{l}\text { Economic level } \\
\text { Low } \\
\text { Not low }\end{array}$ & $\begin{array}{l}274(60.5) \\
941(88.6)\end{array}$ & $\begin{array}{l}179(39.5) \\
121(11.4)\end{array}$ & $<0.001$ \\
\hline
\end{tabular}

${ }^{a}$ Fisher's exact test.

${ }^{b}$ Absolute numbers and percentages (in parentheses).

Discrepancies in totals are due to missing values. 


\begin{tabular}{|c|c|c|c|c|}
\hline \multirow[t]{2}{*}{ Variable } & \multicolumn{2}{|c|}{ Crude (unadjusted) models } & \multicolumn{2}{|c|}{ Multivariable-adjusted models ${ }^{\mathbf{b}}$} \\
\hline & OR $(95 \% C I)^{a}$ & $\mathbf{P}^{\mathbf{a}}$ & OR (95\%CI) & $\boldsymbol{P}$ \\
\hline $\begin{array}{l}\text { Sex } \\
\text { Female } \\
\text { Male }\end{array}$ & $\begin{array}{c}1.2(0.9-1.6) \\
1.0 \text { (reference) }\end{array}$ & 0.135 & $\begin{array}{c}1.0(0.8-1.4) \\
1.0 \text { (reference) }\end{array}$ & 0.896 \\
\hline $\begin{array}{l}\text { Age group } \\
\quad \text { < } 40 \text { years } \\
\quad 40-64.9 \text { years } \\
\geq 65 \text { years }\end{array}$ & $\begin{array}{c}1.1(0.8-1.6) \\
1.4(1.1-1.9) \\
1.0 \text { (reference) }\end{array}$ & $\begin{array}{c}0.046(2)^{c} \\
0.544 \\
0.017 \\
-\end{array}$ & $\begin{array}{c}0.8(0.4-1.6) \\
0.9(0.5-1.5) \\
1.0 \text { (reference) }\end{array}$ & $\begin{array}{c}0.862(2) \\
0.587 \\
0.638 \\
-\end{array}$ \\
\hline $\begin{array}{l}\text { Marital status } \\
\text { Other } \\
\text { Married }\end{array}$ & $\begin{array}{c}1.2(0.9-1.7) \\
1.0 \text { (reference) }\end{array}$ & 0.175 & $\begin{array}{c}1.4(1.0-2.0) \\
1.0 \text { (reference) }\end{array}$ & 0.050 \\
\hline $\begin{array}{l}\text { Place of residence } \\
\text { Rural } \\
\text { Urban }\end{array}$ & $\begin{array}{c}2.1(1.6-2.7) \\
1.0 \text { (reference) }\end{array}$ & $<0.001$ & $\begin{array}{c}1.6(1.2-2.1) \\
1.0 \text { (reference) }\end{array}$ & 0.002 \\
\hline $\begin{array}{l}\text { Educational level } \\
\text { Low (0-8 years) } \\
\text { Middle (9-12 years) } \\
\text { High (( } \geq 13 \text { years })\end{array}$ & $\begin{array}{c}4.3(2.8-6.5) \\
2.3(1.5-3.6) \\
1.0 \text { (reference) }\end{array}$ & $\begin{array}{c}<0.001(2) \\
<0.001 \\
<0.001 \\
\quad-\end{array}$ & $\begin{array}{c}2.1(1.3-3.4) \\
1.6(1.0-2.6) \\
1.0 \text { (reference) }\end{array}$ & $\begin{array}{c}0.009(2) \\
0.003 \\
0.051 \\
-\end{array}$ \\
\hline $\begin{array}{l}\text { Employment status } \\
\text { Employed } \\
\text { Unemployed } \\
\text { Retired }\end{array}$ & $\begin{array}{c}0.7(0.5-1.0) \\
2.6(1.9-3.5) \\
1.0 \text { (reference) }\end{array}$ & $\begin{array}{c}<0.001(2) \\
0.045 \\
<0.001 \\
-\end{array}$ & $\begin{array}{c}1.4(0.8-2.6) \\
2.9(1.6-5.1) \\
1.0 \text { (reference) }\end{array}$ & $\begin{array}{c}<0.001(2) \\
0.255 \\
<0.001 \\
-\end{array}$ \\
\hline $\begin{array}{l}\text { Economic level } \\
\text { Low } \\
\text { Not low }\end{array}$ & $\begin{array}{c}5.1(3.9-6.6) \\
1.0 \text { (reference) }\end{array}$ & $<0.001$ & $\begin{array}{c}4.2(3.2-5.6) \\
1.0 \text { (reference) }\end{array}$ & $<0.001$ \\
\hline
\end{tabular}

OR: nonintake versus intake of drugs prescribed by family physicians, their respective $95 \%$ CIs and P values from binary logistic regression.

${ }^{b}$ Adjusted simultaneously for all variables presented in the table.

'Overall $P$ values and degrees of freedom (in parentheses).

$\mathrm{CI}=$ confidence interval $; \mathrm{OR}=$ odds ratio

\section{Discussion}

This study of a large and almost representative sample of PHC users in Albania showed a high prevalence of nonintake of medication prescribed by family physicians $(18 \%$ in men and $21 \%$ in women). One out of 5 PHC users in not receiving their prescribed medication is a cause for concern. Significant independent correlates of nonintake of medication included rural residence, low educational level, unemployment and, in particular, low economic status. Importantly, these findings persisted upon adjustment for a wide range of demographic characteristics and socioeconomic factors. Evidently, poor and unemployed people can afford less to buy the prescribed drugs. Several socioeconomic factors included in logistic regression models were interconnected (e.g., individuals residing in urban areas or those with a higher education had more possibility to find a job and were less likely to be poor). Nonetheless, each of the 3 main socioeconomic factors (education, employment and economic status) turned out to be independent correlates of medication adherence in multivariable-adjusted models. Therefore, regardless of potential collinearity (a condition in which independent variables are highly correlated), each of these 3 key socioeconomic factors was a strong and significant independent predictor of medication adherence in this study population.
Similar to our findings, a previous study has reported no effect of sex, age, place of residence, body mass index, income, smoking, alcohol consumption, comorbidity and disease activity on medication adherence (30). On multivariate analysis, the predictors of adherence were the combined category of education, occupation and socioeconomic status, and disease duration (30). Another study showed that sex and socioeconomic status do not appear to influence nonadherence (14). Several studies have shown reduced adherence in ethnic minorities. Factors that may predict nonadherence include forgetfulness, illiteracy, inability to understand the purpose of treatment, not perceiving the treatment as necessary, lack of trust in the treatment, a lack of knowledge about the effects of treatment (14).

Morgan and Lee have presented data on the 12-month prevalence of CRNA for medication adherence among adults aged $\geq 55$ years for 11 developed countries (13). Most countries ranged between 1.6\% (France) and 8.3\% (Canada), except the United States of America, which was an outlier with a substantially higher prevalence of CRNA $(16.8 \%)$ (13). In comparison, Albania seemed to have a higher prevalence of CRNA. Our study included individuals aged $\geq 18$ years; however, an analysis restricted to participants aged $\geq 55$ years revealed a prevalence of nonintake of $18 \%$, which is still higher than in all 11 countries included in the study by Morgan and Lee (13). Of note, the outcome 
Table 3 Reasons for not taking medication prescribed by

family physicians among primary health care users

\begin{tabular}{lcc} 
Variable & No. & $\%$ \\
\hline High cost & 273 & 91.0 \\
Negligence & 145 & 48.3 \\
Mistrust in the drugs prescribed & 137 & 45.7 \\
All three reasons & 136 & 45.3 \\
No reason & 7 & 2.3 \\
\hline
\end{tabular}

in the study by Morgan and Lee (12-year prevalence) was not exactly the same, but is nevertheless comparable with our operational definition of medication adherence, as they defined it as having reported CRNA at least once during the last 12 months (13). In our study, the outcome variable (medication adherence) referred to recently prescribed medication, thus, our estimate may be even higher if we include nonadherence during the past year.

Possible reasons for the higher prevalence of CRNA in Albania compared to other countries may include lack of coverage or partial coverage of drug costs by the health insurance scheme (23). Also, another driving factor may consist of the fact that medicines are relatively more expensive in Albania compared to developed countries. Indeed, assessment of prices of some defined drug categories (including antidiabetic and antihypertensive medication) in relation to the general cost of living indicates an unfavourable position of Albania compared to Western countries $(26,27)$. The opposite is evident in countries such as the Netherlands where socioeconomic status is not a predictor of nonadherence, nonpersistence or reinitiation (31). This can be explained by the health insurance coverage of prescribed antihypertensive drugs, a study says (31). In Qatar, a study conducted regarding medication adherence among patients with uncontrolled diabetes showed that, although medicines are available at subsidized cost to Qatari and non-Qatari (only $20 \%$ of the total cost) inividuals, patients from deprived socioeconomic backgrounds found it difficult to pay for their medicines, leading to nonadherence (32). The same was shown in the study conducted on medication adherence, nonpersistence and reinitiation of antihypertensive drugs among patients on oral antidiabetic drugs in the Netherlands where, lower noadherence and nonpersistence rates can be expected, since patients are obliged to have health insurance, which covers most of the costs for prescribed antihypertensive drugs (31). A previous literature review has reported that the reduction of drug expenses through better insurance coverage can improve drug adherence (31). Although we did not assess this outcome, it is worth mentioning a study that showed that many patients reported the inability to understand the prescription or inadequate information about their treatment as a hindrance to medication adherence (30).

Our finding regarding a higher CRNA rate among people with a weaker financial background is not surprising. Nevertheless, the magnitude was remarkable
$(\mathrm{OR}=4.2$ poor vs not poor). Yet, our findings are compatible with a large American study that reported higher CRNA levels associated with a weaker financial background (lower income: $\mathrm{OR}=1.59$, or difficulty to pay bills: $\mathrm{OR}=6.63$ ) (33).

A 2018 study reported that CRN levels were higher among younger individuals, women, poor people and those with serious mental illness (12). Conversely, a survey conducted in Israel in 2012 reported that adherent patients were comparable to nonadherent patients in their demographic and socioeconomic characteristics (34). This study also reported that about $32 \%$ of the patients did not purchase the prescribed medication mainly because of their adverse effects and/or cost (34). Instead, in our study, $91 \%$ of participants did not take the medication because of its cost. A study conducted on adherence to medication in patients with inflammatory bowel disease showed that $6 \%$ of participants did not adhere to medication due to the cost of treatment (30).

There were several limitations to the current study including the possibility of selection and information bias as wells as the study design. This study included a probabilistic nationwide sample of PHC users in several regions of Albania, which points to an almost representative sample of the adult population attending PHC services. Nonetheless, nonusers may be different from users of PHC services regarding selected sociodemographic characteristics. Therefore, our findings cannot be generalized to the overall population, but should be confined to adult PHC users in Albania. Data collection consisted of a straightforward intervieweradministered questionnaire. All the interviewers were properly trained during a 2-day intensive course, and the questionnaire was initially pretested. There was no evidence of any information bias, given the initial pretesting of the instrument and also the proper training of all the interviewers regarding data collection and recording. Nevertheless, we cannot entirely exclude the differential reporting of medication adherence and/or the reasons for nonintake between various sociodemographic groups. Many factors are associated with nonadherence and they were not included in this study. Also, we did not include individuals who were seriously ill. It would have been interesting to know whether about $20 \%$ of the seriously ill individuals would not have taken the prescribed medication for financial reasons. The specific types of medication prescribed by the family physicians were not assessed in this study. A limitation of this study relates to the impossibility of defining the threshold for taking or not taking the prescribed medication (i.e., what price was perceived as too high). It would be interesting knowing if the patients refused to take relevant or essential medicines; information which was not retrieved in the current study. Finally, associations pertinent to cross-sectional studies are not assumed to be causal and, therefore, should be interpreted with caution. 


\section{Conclusion}

Our study provides valuable and novel evidence about the extent and sociodemographic determinants of medication adherence among adult PHC users in a transitional South Eastern European population. Our findings should be replicated and confirmed in future studies and in different settings. Apparently, the magnitude of nonintake of medication is primarily linked to financial constraints, affecting especially the low socioeconomic groups and other vulnerable and marginalized population categories.
Decision-makers and policy-makers in Albania and elsewhere should consider the provision of essential medication free-of-charge or at very low cost to poor and lowly educated people, because the costs of noncompliance will be eventually higher.

Funding: This study was funded by the "Health for All Project" in Albania (hap.org.al), which is a project of the Swiss Agency for Development and Cooperation (SDC).

Competing interests: None declared.

\section{Prévalence et corrélats sociodémographiques de l'observance thérapeutique chez les usagers des soins de santé primaires en Albanie}

\section{Résumé}

Contexte: Les données sur l'ampleur et les déterminants de l'observance thérapeutique chez les patients et dans la population générale en Europe du Sud-Est sont rares.

Objectifs : Évaluer la prévalence et les corrélats sociodémographiques de l'observance thérapeutique chez les usagers des soins de santé primaires adultes en Albanie.

Méthodes : Une étude transversale a été menée en 2018-2019 auprès d'un échantillon représentatif de 1553 adultes usagers des soins de santé primaires (taux de réponse : $94 \%$ ) sélectionnés de manière aléatoire dans cinq grandes régions d'Albanie. Il s'agissait de 849 femmes (55\%) et 704 hommes (45\%), dont lâge moyen était de 54,6 ans (16,4). Un questionnaire structuré administré par un enquêteur a permis de s'enquérir de l'observance thérapeutique pour les médicaments prescrits par les médecins de famille, et des caractéristiques sociodémographiques. La régression logistique binaire a été utilisée pour évaluer les corrélats sociodémographiques de l'observance thérapeutique.

Résultats : Trois cents participants (19,8\%) n'ont pas pris les médicaments prescrits. Dans le modèle logistique ajusté multivarié, les corrélats significatifs de la non-prise de médicaments comprenaient la résidence rurale, le faible niveau d'éducation, le chômage et le faible niveau économique. Parmi ces 300 participants, 273 (91\%) ont considéré le coût élevé des médicaments comme une raison de ne pas les prendre.

Conclusion: Nous avons constaté une forte prévalence de la non-prise de médicaments prescrits par les médecins de famille. Les décideurs et les responsables de l'élaboration des politiques en Albanie et ailleurs devraient envisager la fourniture de médicaments essentiels gratuitement ou à un coût très bas pour les groupes à faible revenu et les autres catégories de population vulnérables et marginalisées, car le coût de la non-observance sera en fin de compte plus élevé.

$$
\begin{aligned}
& \text { الانثشار والارتباطات الاجتياعية السكانية للالتزام بتناول الدواء بين مستخدمي الرعاية الصحية الأولية في ألبانيا } \\
& \text { دجانا روشي، جينك بورازيري، سالفاتوري إيطاليا، بيتر شرودر-بيك، ألبان إيلي، هيلموت براند } \\
& \text { الخلاصة } \\
& \text { الخلفية: لا توجد أدلة تُذكر على حجم الالتزام بتناول الدواء ومحدداته بين المرضى وعموم السكان في جنوب شرق أوروبا. } \\
& \text { الأهداف: هدفت هذه الدراسة إلى تقييم مدى الانتشار والارتباطات الاجتهاعية السكانية للالتزام بتناول الدواء بين مستخدمي الرعاية الصحية } \\
& \text { الأولية في ألبانيا. }
\end{aligned}
$$

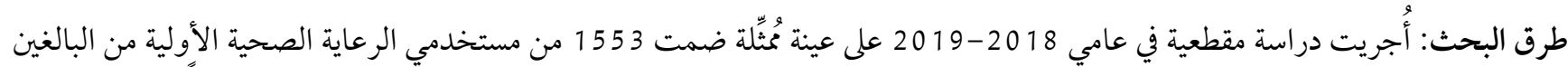

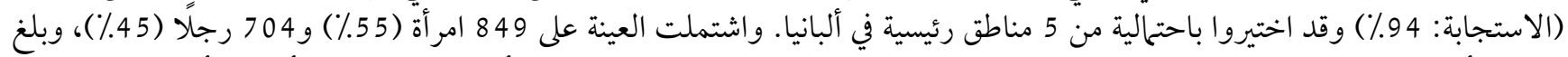

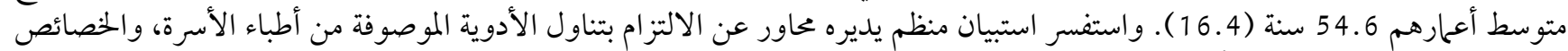

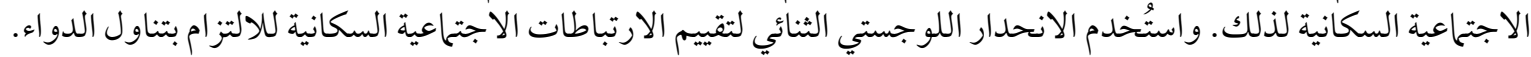

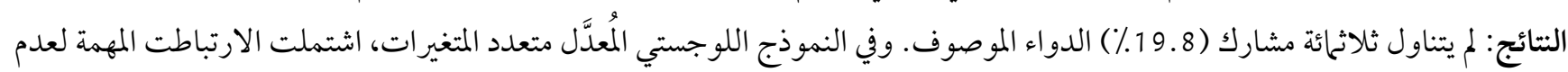

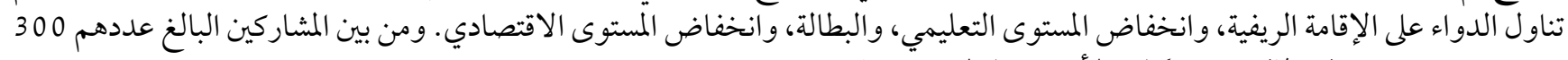

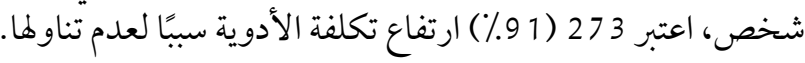

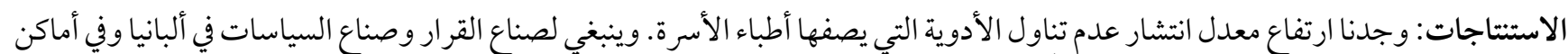

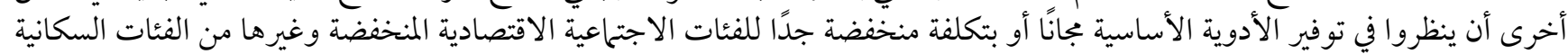

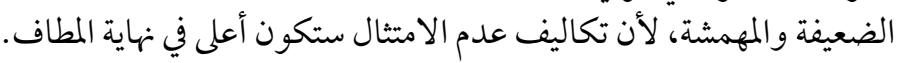




\section{References}

1. Panteli D, Eckhardt H, Nolting A, Busse R, Kulig M. From market access to patient access. Overview of evidence-based approaches for the reimbursement and pricing of pharmaceuticals in 36 European countries. Health Res Policy Syst. 2015 Sep 25;13:39-47. https://doi.org/10.1186/s12961-015-0028-5 PMID:26407728

2. Aaserud M, Dahlgren AT, Kösters JP, Oxman AD, Ramsay C, Sturm H. Pharmaceutical policies: effects of reference pricing, other pricing, and purchasing policies. Cochrane Database Syst Rev. 2006 Apr 19; 2: CDo05979. https://doi.org/10.1002/14651858. CDoo5979 PMID:16625648

3. Vogler S. The impact of pharmaceutical pricing and reimbursement policies on generics uptake: implementation of policy options on generics in 29 European countries - an overview. GaBI Journal. 2012;1(2):93-100. https://doi.org/10.5639/gabij.2012.0102.020

4. Vogler S, Paris V, Ferrario A, Wirtz VJ, de Joncheere K, Schneider P et al. How Can Pricing and Reimbursement Policies Improve Affordable Access to Medicines? Lessons Learned from European Countries. Appl Health Econ Health Policy. 2017 Jun;15(3):30721. https://doi.org/10.1007/s40258-016-0300-z PMID:28063134

5. Luiza VL, Chaves LA, Silva RM, Emmerick IC, Chaves GC, Fonseca de Araújo SC et al. Pharmaceutical policies: effects of cap and co-payment on rational use of medicines. Cochrane Database Syst Rev. May 8;2015(5):CDoo7017. https://doi. org/10.1002/14651858.CDoo7017.pub2 PMID:25966337

6. Vogler S, Zimmermann N, Leopold C, de Joncheere K. Pharmaceutical policies in European countries in response to the global financial crisis. South Med Rev. 2011 Dec;4(2):69-79. https://doi.org/10.5655/smr.v4i2.1004 PMID:23093885

7. Acosta A, Ciapponi A, Aaserud M, Vietto V, Austvoll-Dahlgren A, Kösters JP et al. Pharmaceutical policies: Effects of reference pricing, other pricing, and purchasing policies. Cochrane Database Syst Rev. 2014;(10):CDo05979. https://doi/. org/10.1002/14651858.CDoo5979.pub2

8. Srivastava D, McGuire A. Analysis of prices paid by low-income countries - How price sensitive is government demand for medicines? BMC Public Health. 2014; 14:767. https://doi.org/10.1186/1471-2458-14-767

9. Primary health care in Albania: rapid assessment. Copenhagen: World Health Organization; 2018 (http://www.euro.who.int/_ data/assets/pdf_file/oo11/373718/alb-phc-ra-eng.pdf?ua=1, accessed 8 February 2021).

10. Osteberg L, Blaschke T. Adherence to medication. N Engl J Med. 2005 Aug 4;353(5):487-97. http://doi.org/10.1056/NEJMrao50100 PMID:16079372

11. Cramer JA, Roy A, Burrell A, Fairchild CJ, Fuldeore MJ, Ollendorf DA et al. Medication compliance and persistence: terminology and definitions. Value Health. 2008 Jan-Feb;11(1):44-7. https://doi.org/10.1111/j.1524-4733.2007.00213.x PMID:18237359

12. Lee S, Jiang L, Dowdy D, Hong YA, Ory MG. Attitudes, beliefs, and cost-related medication nonadherence among adults aged 65 or older with chronic diseases. Prev Chronic Dis. 2018 Dec 6;15:1-10. http://dx.doi.org/10.5888/pcd15.180190

13. Morgan SG, Lee A. Cost-related non-adherence to prescribed medicines among older adults: A cross-sectional analysis of a survey in 11 developed countries. BMJ Open. 2017 Jan 31;7(1):e014287. https://doi.org/10.1136/bmjopen-2016-014287 PMID:28143838

14. Yuvaraj K, Gokul S, Sivaranjini K, Manikandanesan S, Murali S, Gayathri S, Majella MG, Kumar SG. Prevalence of medication adherence and its associated factors among patients with noncommunicable disease in rural Puducherry, South India - a facility-based cross-sectional study. J Family Med Prim Care. 2019 Feb;8(2):701-5. https://doi.org/10.4103/jfmpc.jfmpc_350_18 PMID:30984698

15. William HP, Robert RH. Poor medication adherence in type 2 diabetes: recognizing the scope of the problem and its key contributors. Patient Prefer Adherence. 2016 Jul 22;10:1299-307. https://doi.org/10.2147/PPA.S106821 PMID:27524885

16. Doucet J. Cost-related nonadherence to medications and pharmacare. Canadian Oncol Nursing. 2017 Oct 1;27(4):390-91. PMID:31148777

17. Piette JD, Beard A, Rosland AM, McHorney CA. Beliefs that influence cost-related medication non-adherence among the "haves" and "have nots" with chronic diseases. Patient Prefer Adherence. 2011;5:389-96. https://doi.org/10.2147/PPA.S23111 PMID:21949602

18. Burazeri G, Kark JD. Negative attitudes to transition in post-communist Albania and acute coronary syndrome. Health Psychol. 2009 Nov;28(6):779-86. https://doi.org/10.1037/a0015987 PMID:19916647

19. Burazeri G, Goda A, Sulo G, Stefa J, Kark JD. Financial loss in pyramid savings schemes, downward social mobility and acute coronary syndrome in transitional Albania. J Epidemiol Community Health. 2008 Jul;62(7):620-6. https://doi.org/10.1136/ jech.2007.066001 PMID:18559445

20. National health report: health status of the Albanian population. Tirana: Institute of Public Health; 2014 (http://ishp.gov.al/ wp-content/uploads/2015/04/Health-report-English-version.pdf, accessed 8 February 2021).

21. Albanian National Health Strategy 2016-2020. Ministry of Health of the Republic of Albania; 2016 (https://shendetesia.gov.al/ wp-content/uploads/2019/01/Health-Strategy 2020_en g.pdf, accessed 18 April 2019).

22. Republic of Albania. Law No. 10 383, date 24.02.2011. On Compulsory Health Insurance in the Republic of Albania; 2011 (https:// www.fsdksh.com.al/images/stories/ baza_ligjore/11janar2016/Ligj_nr_10_383_dat_24_2_2011_Pr_sigurimin_e_detyrueshm_t_kujdesit_shndetsor_n_Republikn_Shqipris_i_ndryshuar.pdf , accessed 28 March 2019). 
23. Beneficiary categories from the compulsory health insurance scheme in Albania. Compulsory Health Insurance Fund of the Republic of Albania; 2017 (https://www.fsdksh.com.al/k ush-p\%C3\%ABrfiton/87-kush-perfiton-perfituesit, accessed 18 April 2019).

24. Decree No. 101, date 27.2.2019. For a change in the Decree No. 218, date 20.4.2018, On the approval of the medication list which are reimbursed by the Health Insurance. Council of Minister of the Republic of Albania; 2018 (https://www.fsdksh.com.al/aktivitete/742-njo ftim-mbi-list\% $\mathrm{C} 3 \% \mathrm{ABn}$-e-barnave-t\%C3\%AB-rimbursueshme-me-\%C3\%A7mimet-e-indeksuara, accessed 18 April 2019).

25. Hotchkiss DR, Hutchinson PL, Malaj A, Berruti AA. Out-of-pocket payments and utilization of health care services in Albania: evidence from three districts. Health Policy. 2005 Dec;75(1):18-39. https://doi.org/10.1016/j.healthpol.2005.02.003 PMID:16298226

26. Tomini S, Packard TG. Catastrophic and impoverishing effects of out-of-pocket payments for health care in Albania: evidence from Albania Living Standards Measurement Surveys 2002, 2005 and 2008. Health Policy Plan. 2013 Jul;28(4):419-28. https://doi. org/10.1093/heapol/czs073 PMID:22907092

27. Tomini SM, Groot W, Pavlova M, Tomini F. Paying Out-of-pocket and informally for health care in Albania: the impoverishing effect on households. Front Public Health. 2015 Aug 28;3:207. https://doi.org/10.3389/fpubh.2015.00207 PMID:26380252

28. Abramson JH, Gahlinger PM. Computer programs for epidemiologists: PEPI version 11.15. Salt Lake City: Sagebrush Press; 2011.

29. Hosmer D, Lemeshow S. Applied logistic regression. New York: Wiley \& Sons; 1989.

30. Sanjeevani KT, Saurabh K, Namrata S, Ashish D.U, Nagesh K, Sawan B, Dawesh PY, Sandeep G, Saransh J, Govind M, Vineet A. Higher education, professional occupation, and upper socioeconomic status are associated with lower adherence to medications in patients with inflammatory bowel disease. JGH Open. 2019 Mar 18;3(4):302-9. https://doi.org/10.1002/jgh3.12160 PMID:31406923

31. Alfian SD, Denig P, Coelho A, Hak E. Pharmacy-based predictors of nonadherence, non-persistence and reinitiation of antihypertensive drugs among patients on oral diabetes drugs in the Netherlands. PLoS One. 2019 Nov 15; 14(11):e0225390. https://doi. org/10.1371/journal.pone.0225390 PMID:31730627

32. Myriam J, Muhammad AH, Nadir K, Mohamed IMI, Mohammad ID, Samya AA, Ahmed A. A qualitative exploration of barriers to medication adherence among patients with uncontrolled diabetes in Qatar: integrating perspectives of patients and health care providers. Patient Prefer Adherence. 2018 Oct 17;12:2205-16. https://doi.org/10.2147/PPA.S174652 PMID:30410316

33. Zhang JX, Crowe JM, Meltzer DO. The differential rates in cost-related non-adherence to medical care by gender in the US adult population. J Med Econ. 2017 Jul;20(7):752-9. https://doi.org/10.1080/13696998.2017.1326383 PMID:28466689

34. Simon-Tuval T, Triki N, Chodick G, Greenberg D. Determinants of cost-related nonadherence to medications among chronically ill patients in maccabi healthcare services, Israel. Value Heal Reg Issues. 2014 Sep;4:41-6. https://doi.org/10.1016/j.vhri.2014.06.010 PMID:29702805 